\title{
Activin plays a key role in the maintenance of long-term memory and late-LTP
}

\author{
Hiroshi Ageta, ${ }^{1,2,3}$ Shiro Ikegami, ${ }^{1}$ Masami Miura, ${ }^{4}$ Masao Masuda, ${ }^{4}$ Rika Migishima, ${ }^{1}$ \\ Toshiaki Hino, ${ }^{1}$ Noriko Takashima, ${ }^{1,2}$ Akiko Murayama, ${ }^{1,2}$ Hiromu Sugino, ${ }^{5}$ \\ Mitsutoshi Setou, ${ }^{1,6}$ Satoshi Kida, ${ }^{2,7}$ Minesuke Yokoyama, ${ }^{1,8}$ Yoshihisa Hasegawa, ${ }^{9}$ \\ Kunihiro Tsuchida, ${ }^{3}$ Toshihiko Aosaki, ${ }^{4}$ and Kaoru Inokuchi ${ }^{1,2,8,10,11}$
}

${ }^{1}$ Mitsubishi Kagaku Institute of Life Sciences, MITILS, Machida, Tokyo 194-8511, Japan; ${ }^{2}$ Japan Science and Technology Agency, CREST, Kawaguchi, Saitama 332-0012, Japan; ${ }^{3}$ Institute for Comprehensive Medical Science, Fujita Health University, Aichi $470-$ 1192, Japan; ${ }^{4}$ Neuropathophysiology Research Group, Tokyo Metropolitan Institute of Gerontology, Tokyo 173-0015, Japan; ${ }^{5}$ National Institute of Advanced Industrial Science and Technology, Tsukuba 305-8562, Japan; ${ }^{6}$ Molecular Imaging Advanced Research Center, Department of Molecular Anatomy, Hamamatsu University School of Medicine, Hamamatsu, Shizuoka 431-3192, Japan; ${ }^{7}$ Department of Agricultural Chemistry and Bioscience, Faculty of Applied Science, Tokyo University of Agriculture, Tokyo 1568502, Japan; ${ }^{8}$ Brain Research Institute, Niigata University, Niigata 951-8585, Japan; ${ }^{2}$ Laboratory Animal Science, Kitasato University School of Veterinary Medicine and Animal Sciences, Towada, Aomori 034-8628, Japan; ${ }^{10}$ Department of Biochemistry, Faculty of Medicine, Graduate School of Medicine and Pharmaceutical Sciences, University of Toyama, Toyama 930-0194, Japan

\begin{abstract}
A recent study has revealed that fear memory may be vulnerable following retrieval, and is then reconsolidated in a protein synthesis-dependent manner. However, little is known about the molecular mechanisms of these processes. Activin $\beta A$, a member of the TGF- $\beta$ superfamily, is increased in activated neuronal circuits and regulates dendritic spine morphology. To clarify the role of activin in the synaptic plasticity of the adult brain, we examined the effect of inhibiting or enhancing activin function on hippocampal long-term potentiation (LTP). We found that follistatin, a specific inhibitor of activin, blocked the maintenance of late LTP (L-LTP) in the hippocampus. In contrast, administration of activin facilitated the maintenance of early LTP (E-LTP). We generated forebrain-specific activin- or follistatin-transgenic mice in which transgene expression is under the control of the Tet-OFF system. Maintenance of hippocampal L-LTP was blocked in the follistatintransgenic mice. In the contextual fear-conditioning test, we found that follistatin blocked the formation of long-term memory (LTM) without affecting short-term memory (STM). Furthermore, consolidated memory was selectively weakened by the expression of follistatin during retrieval, but not during the maintenance phase. On the other hand, the maintenance of memory was also influenced by activin overexpression during the retrieval phase. Thus, the level of activin in the brain during the retrieval phase plays a key role in the maintenance of long-term memory.
\end{abstract}

[Supplemental material is available online at http://www.learnmem.org.]

Formation of long-term memory (LTM) consists of several distinct processes: acquisition, consolidation, and reconsolidation, through which memory becomes permanent (Nader et al. 2000; Rodrigues et al. 2004; Tronson and Taylor 2007; Kitamura et al. 2009). The prominent feature of LTM is a requirement for RNA and protein synthesis for consolidation and reconsolidation (Squire and Barondes 1973; Bourtchuladze et al. 1994; Silva et al. 1998; Tronson and Taylor 2007; Lee et al. 2008). The reconsolidation process may serve to strengthen or renew the original fear memory (Nader 2003; Tronson and Taylor 2007). Synaptic plasticity is thought to underlie memory formation. Recent studies have shown that the learning process induces long-term potentiation (LTP) (Rogan et al. 1997; Rioult-Pedotti et al. 2000), a form of synaptic plasticity, and, conversely, that LTP is necessary for memory formation (Rodrigues et al. 2004). Similar to LTM,

\footnotetext{
${ }^{11}$ Corresponding author.
}

Email inokuchi@med.u-toyama.ac.jp; fax 81-76-434-5014

Article is online at http://www.learnmem.org/cgi/doi/10.1101//m.16659010.
LTP requires protein and RNA synthesis for its prolonged maintenance, late LTP (L-LTP) (Frey et al. 1988; Abraham et al. 1993; Nguyen et al. 1994; Fukazawa et al. 2003).

In order to understand the molecular mechanism of LTM, we previously isolated a number of neuronal activity-dependent genes, including activin $\beta A$, ubiquitin C-terminal hydrolase, vesl-1S/homer-1a, and SCRAPPER (Inokuchi et al. 1996; Hegde et al. 1997; Kato et al. 1997; Yao et al. 2007; Okada et al. 2009). Activin $\beta A$, a member of the TGF- $\beta$ superfamily (Massague 1998), is one of the genes whose expression is up-regulated following L-LTP induction (Andreasson and Worley 1995; Inokuchi et al. 1996). Activin is a multifunctional ligand that regulates the proliferation and differentiation of numerous cell types (Mather et al. 1997; Ying et al. 1997). Activin binds to the serine/threonine kinase receptor activin type II (ActRII) that is located on the cell membrane (Pangas and Woodruff 2000). Once ligand is bound, the type II receptor recruits and phosphorylates an activin type I receptor (ActRI). Following stimulation by activin, the transcription factors Smad2 and Smad3 are phosphorylated by ActRI 
(Pangas and Woodruff 2000). Activin receptor ActRII is highly expressed in the forebrain region (Cameron et al. 1994; Funaba et al. 1997), and its scaffold protein ARIP/S-SCAM is also localized to the synaptic region (Hirao et al. 1998; Shoji et al. 2000).

Recent studies reveal that activin regulates the morphology of dendritic spines (Shoji-Kasai et al. 2007) and neurogenesis (Ageta et al. 2008; Abdipranoto-Cowley et al. 2009; Sekiguchi et al. 2009), has a neuroprotective function (Tretter et al. 2000), and plays a role in anxiety-related behavior (Dow et al. 2005; Ageta et al. 2008; Zheng et al. 2008). We previously found that activin increases the number of synaptic contacts and the length of dendritic spine necks by modulating spinal actin dynamics (Shoji-Kasai et al. 2007). We hypothesized that activin modulates spine actin dynamics and that this in turn affects LTP persistence. Furthermore, activin induces phosphorylation of the $N$-methylD-aspartate receptor (NMDAR), a key component in the formation of LTP (Nicoll and Malenka 1999), and increases $\mathrm{Ca}^{2+}$ influx through NMDAR (Kurisaki et al. 2008). This activin-induced NMDAR activation persists for $>24 \mathrm{~h}$. These results suggest that activin has an important role in the formation of L-LTP and LTM.

\section{Results}

Activin is indispensable for in vivo L-LTP

We examined the hippocampal dentate gyrus LTP of urethaneanesthetized rats. A strong high-frequency stimulation (HFS, five 400-pulse trains at $400 \mathrm{~Hz}$ ) produced a long-lasting L-LTP in vivo that persisted for $24 \mathrm{~h}$ (Fig. 1A). However, when the activin inhibitor follistatin $(0.5 \mu \mathrm{g})$ (Nakamura et al. 1990; Sugino et al. 1997) or an anti-activin A antibody $(0.6 \mu \mathrm{g})$ was pre-injected into the lateral ventricle, the strong HFS induced an LTP that
A

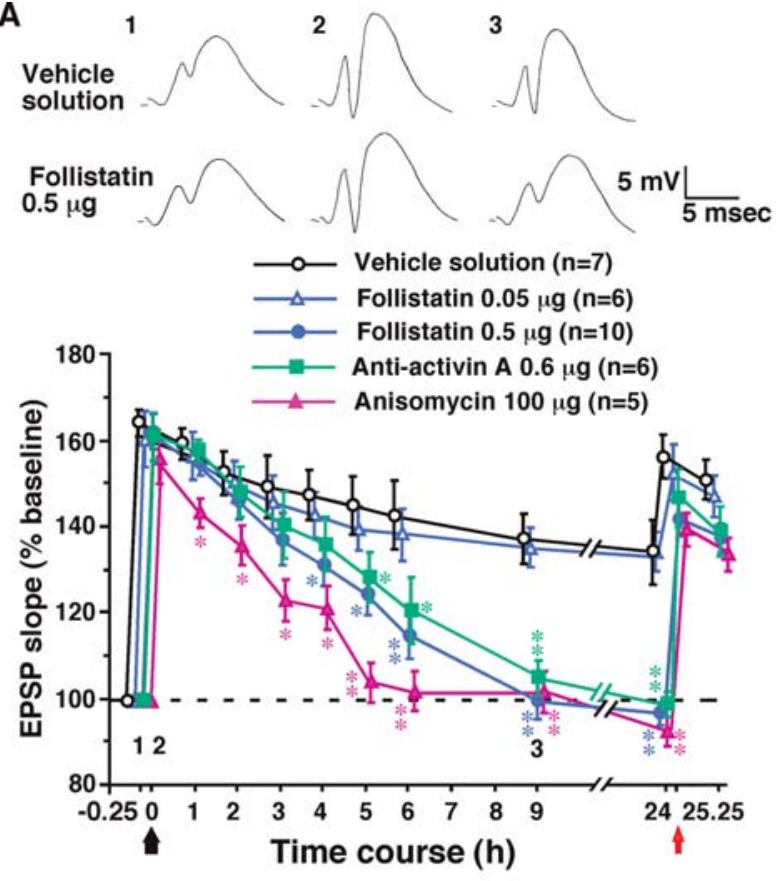

B
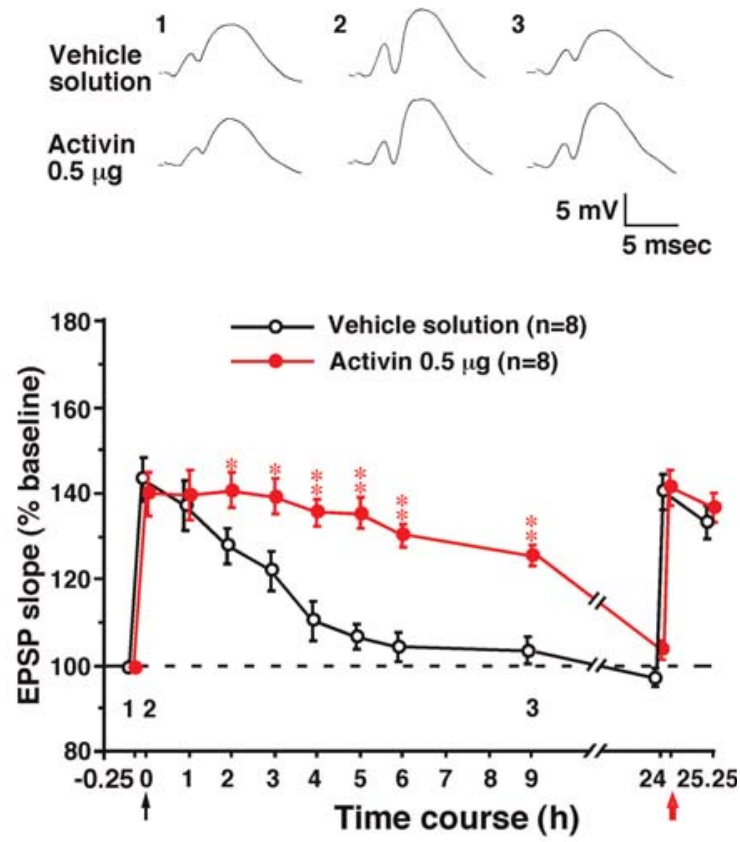

C

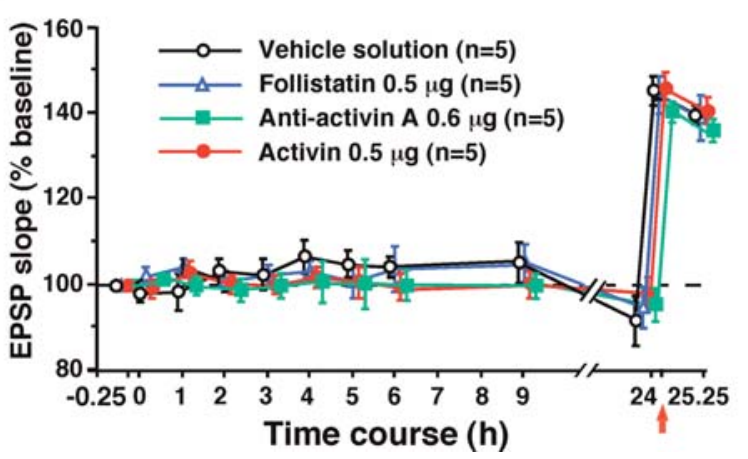

Figure 1. Activin is required for the maintenance of dentate gyrus L-LTP in vivo. (A) Effect of follistatin, anti-activin A, and anisomycin on LTP persistence. A strong HFS was delivered at time 0 (thick arrow). (B) Effect of activin on LTP persistence. A weak HFS was delivered at time 0 (thin arrow). (C) Basal synaptic transmission was not affected by follistatin, anti-activin A, or activin. The average of the fEPSP slope during the 15 min prior to time 0 served as the baseline $(100 \%)$ for all trials. $\left({ }^{*}\right) P<0.05,\left({ }^{*}\right) P<0.005$ between the vehicle and experimental groups as determined by one-way ANOVA followed by Fisher's LSD test. At the end of each experiment, a second HFS (100 pulses at $100 \mathrm{~Hz}$ ) was delivered (red arrows at $24 \mathrm{~h}$ ). (Top panels in $A, B$ ) Typical fEPSP traces evoked at the times $(1,2$, or 3$)$ indicated in each graph. Error bars indicate SEM. 
decayed rapidly and returned to basal levels by $9 \mathrm{~h}$ (Fig. 1A). The decay time course is similar to that of animals injected with the protein synthesis inhibitor anisomycin (Fig. 1A). In contrast, follistatin or anti-activin A had no significant effect on the initial amplitude and early maintenance of LTP (E-LTP). The effect of follistatin was dose-dependent because the injection of a lower dose $(0.05 \mu \mathrm{g})$ did not alter the maintenance of L-LTP (Fig. 1A). To exclude the possibility that the LTP decay caused by follistatin or the anti-activin A antibody was due to irreversible damage to hippocampal neurons, a second HFS (100 pulses at $100 \mathrm{~Hz})$ was applied to the same pathway at the end of each experiment $(24 \mathrm{~h})$. We observed an enhancement of the field excitatory postsynaptic potential (fEPSP) slope in all animals (Fig. 1A), which eliminates the possibility that neuronal damage occurred.

In a complementary experiment where activin was preinjected into the lateral ventricle, we used a weak HFS (a 50-pulse train at $100 \mathrm{~Hz}$ ). The weak HFS alone elicited E-LTP that returned to the basal level by $6 \mathrm{~h}$ (Fig. 1B). However, pre-administration of activin facilitated the maintenance of LTP, since the weak HFS under these conditions produced an LTP that lasted $>9 \mathrm{~h}$. Injection of follistatin, anti-activin A, or activin into the lateral ventricle had no significant effect on basal synaptic transmission (Fig. 1C).

When injected $1 \mathrm{~h}$ after the delivery of the weak HFS, activin still enhanced E-LTP (Supplemental Fig. S1A). However, activin failed to facilitate LTP maintenance when administered $3 \mathrm{~h}$ after the weak HFS. Consistent with this result is the observation that the inhibitory effect of follistatin on L-LTP establishment was observed when it was injected $1 \mathrm{~h}$, but not $3 \mathrm{~h}$, after the delivery of the strong HFS (Supplemental Fig. S1B).

\section{Generation of activin and follistatin transgenic mice using a forebrain-specific Tet-OFF system}

To examine the role activin plays in fear memory formation, activin activity was genetically suppressed or increased in the forebrain of transgenic mice carrying a Tet-OFF system. In this system, the tetracycline-controlled transactivator (tTA) is under the control of the CaMKII $\alpha$ promoter to achieve forebrain-specific expression (Fig. 2A; Mayford et al. 1996). We generated two distinct lines of responder mice, ABI and FBI, in which activin and follistatin, respectively, were controlled by the tetracycline response element (TRE) promoter. Double (FBItTA and ABItTA)transgenic mice were obtained by heterozygous crossings. A diet containing DOX $(6 \mathrm{mg} / \mathrm{g}$ food) was fed to pregnant mice for 7 consecutive days immediately prior to the expected date of confinement to reduce leak expression of follistatin or activin during the late embryonic stage. Double-transgenic ABItTA and FBItTA mice were fertile, bred normally, and maintained a normal body weight under the no-DOX treatment.

The tTA binds specifically to the TRE promoter and activates transcription in the absence of DOX (Mayford et al. 1996). In these mice, TRE bidirectionally regulated LacZ (Fig. 2A). Thus, LacZ activity was detected in some brain regions including the hippocampus, striatum, and amygdala in ABItTA, but not ABI, mice in the absence of DOX treatment. LacZ activity was also detected in some brain regions including the hippocampus and cortex in FBItTA, but not FBI, mice in the absence of DOX treatment (Fig. 2B; Supplemental Fig. S2). An ELISA analysis revealed that the activin level in the hippocampus of $\mathrm{ABI}$ mice $(0.06 \mathrm{ng} /$ $\mathrm{mg}$ protein, Fig. 2C) was equivalent to that of wild-type mice (Ageta et al. 2008), showing no leaky transgene expression in ABI mice. Moreover, the follistatin level in the hippocampus of FBItTA mice $(0.25-0.5 \mathrm{ng} / \mathrm{mg}$ protein) was sufficient to antagonize the endogenous hippocampal activin $(0.06 \mathrm{ng} / \mathrm{mg}$ protein) in the absence of DOX treatment (Sugino et al. 1997). DOX administration decreased the ectopic activin and follistatin to basal levels within $3 \mathrm{~d}$ in the hippocampus of ABItTA and FBItTA mice (Fig. 2C). Suppression by DOX was reversible and almost completely recovered within $3 \mathrm{~d}$ for FBItTA and $14 \mathrm{~d}$ for ABItTA (Fig. 2C). There was no significant difference in the activin level in the hippocampus of ABI and ABItTA mice on days 1 and 7 (Fig. 2C). No transgene expression was observed in the cerebellum and medulla of ABItTA and FBItTA mice in the absence of DOX treatment.

\section{The maintenance of L-LTP is reduced in FBItTA mice}

Hippocampal slices were prepared from 6- to 10-wk-old FBI and FBItTA mice, and fEPSPs were recorded in the hippocampal CA1 region after the application of single test stimulus every $20 \mathrm{sec}$ $(0.05 \mathrm{~Hz})$ to the Schaffer collaterals. We first examined whether the basic property of excitatory synaptic transmission was normal in FBItTA mice. We measured the initial slope of fEPSP in order to quantify the strength of the synaptic response. The input-output relationship in FBItTA mice was similar to that of FBI mice (Fig. 3A). In the CA1 region, paired stimulation with short intervals usually causes paired-pulse facilitation (PPF). The extent of PPF with interpulse intervals of $25-500 \mathrm{msec}$ of FBItTA mice was identical to that of FBI mice (Fig. 3B). These results suggest that there are no physiological differences in the basic properties of excitatory synaptic transmission between FBItTA and FBI mice.

We then examined whether E-LTP in the CA1 region was altered in FBItTA mice. After a baseline recording of at least $15 \mathrm{~min}$, LTP was induced by tetanic stimulation. A single train of tetanic stimulation, $100 \mathrm{~Hz}$ for $1 \mathrm{sec}$, elicited identical E-LTP in both strains of mice $(136.2 \pm 14.0 \%$ and $144.8 \pm 16.0 \%$, 90-120 min after tetanic stimulation in FBItTA and FBI mice, respectively). Three trains of tetanic stimulation at 20-sec intervals caused much larger E-LTP than that after a single train of tetanus, but E-LTP in FBItTA mice was similar to that in FBI mice $(161.8 \pm 9.3 \%$ and $175.8 \pm 8.0 \%, 90-120 \mathrm{~min}$ after tetanic stimulation in FBItTA and FBI mice, respectively; Fig. 3C). Thus, E-LTP was unaffected in FBItTA mice.

In contrast, L-LTP in FBItTA mice was markedly reduced as compared with the robust L-LTP observed in FBI mice (Fig. 3C). The slope of fEPSP $3-3.5 \mathrm{~h}$ and $5-5.5 \mathrm{~h}$ after tetanic stimulation in FBItTA mice was $148.6 \pm 11.0 \%$ and $139.0 \pm 10.2 \%$, whereas that in FBI mice was $174.6 \pm 10.2 \%$ and $167.6 \pm 13.2 \%$, respectively $(P<0.05)$. The fEPSPs elicited by stimulation of the second pathway to activate an independent set of Schaffer collaterals were unaltered throughout the experiment in both strains of mice. To clarify the biochemical effect of follistatin transgene expression, we analyzed the phosphorylation level of Smad 2/3 in the hippocampus of FBI and FBItTA. Phosphorylation of Smad 2/3 was significantly decreased in the hippocampus of FBItTA but not FBI (Supplemental Fig. S3). These results demonstrate that L-LTP was reduced in FBItTA mice, whose follistatin levels had an ability to suppress endogenous activin activity in the hippocampus.

\section{Anxiety levels of ABItTA and FBItTA}

Activin has multiple roles in the brain; for example, it influences anxiety-related behavior (Dow et al. 2005; Ageta et al. 2008; Zheng et al. 2008), modulates postnatal neurogenesis (Ageta et al. 2008), and protects neurons from ischemic damage (Tretter et al. 2000). In our previous study, we generated ACM4 and FSM transgenic mice in which activin and follistatin, respectively, were overexpressed in a forebrain-specific manner under the control of the $\alpha$ CaMKII promoter. FSM mice exhibited enhanced anxiety compared with wild-type littermates, while ACM4 mice showed reduced anxiety (Ageta et al. 2008). Therefore, we performed two behavioral analyses, such as a light and dark test and 
A

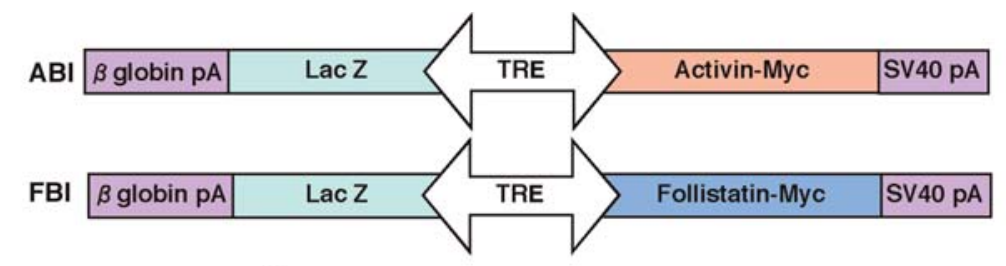

B
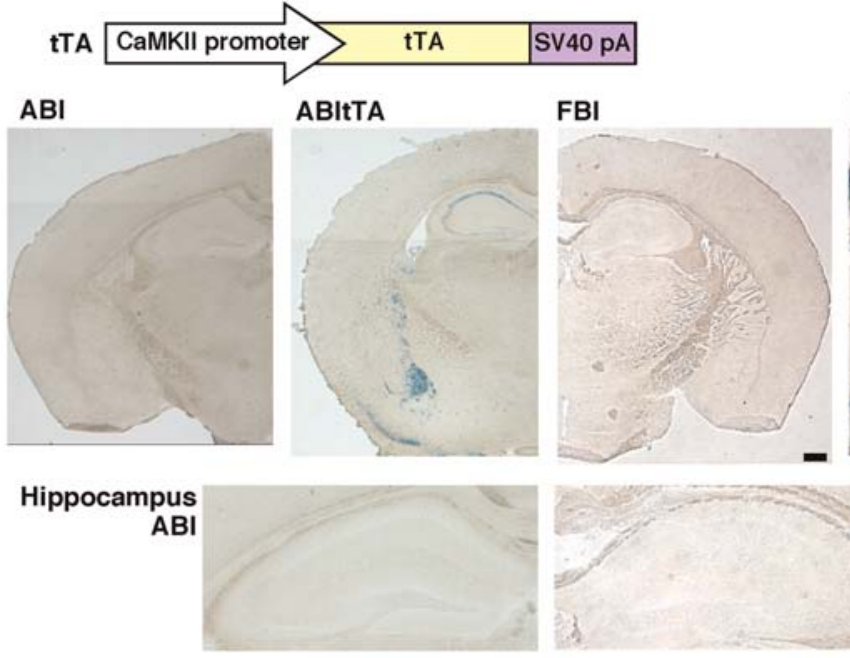

\section{FBItTA}
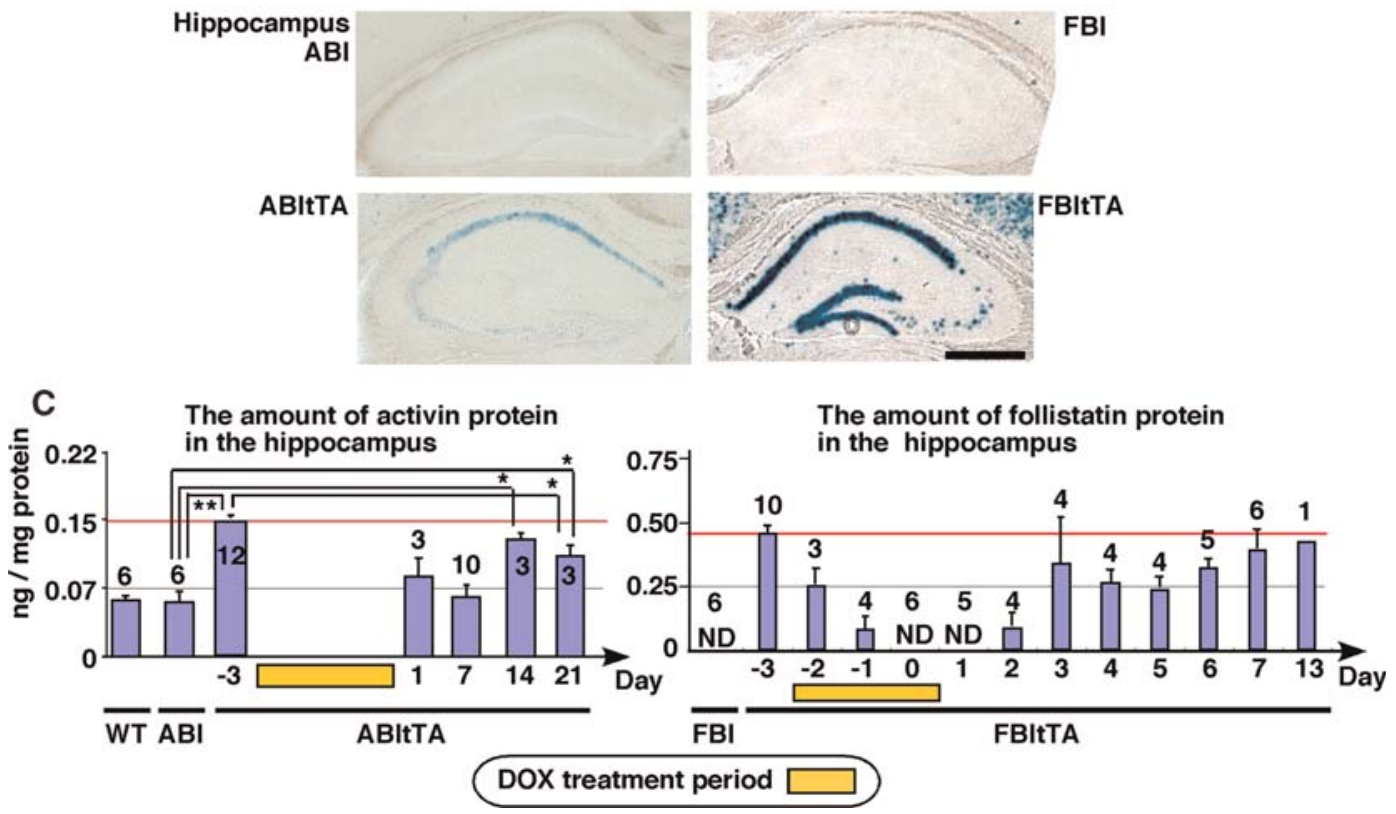

Figure 2. Generation of activin and follistatin transgenic mice using a forebrain-specific Tet-OFF system. $(A)$ Schematic transgene representations of $A B I$ (upper), $\mathrm{FBI}$ (middle), and tTA (lower) constructs. (TRE) Tetracycline response element, (tTA) tetracycline-controlled transactivtor, (pA) polyadenylation signal. (B) X-gal staining. (Upper row) Coronal brain sections from ABI, ABItTA, FBI, and FBItTA mice (10-15 wk old). (Lower row) Enlarged images of the hippocampus. Scale bars, $500 \mu \mathrm{m}$. (C) Measurement of activin and follistatin level using an ELISA assay with anti-activin and anti-follistatin antibodies. (Red line) Maximal levels of activin (left panel) or follistatin (right panel) in the hippocampus in the absence of DOX (10-15 wk old). Mice were fed DOX for 3 consecutive days (from noon of day -3 to noon of day 0 , orange bars). The animals were then sacrificed and the hippocampus was dissected out in the afternoon of the day indicated and used for the ELISA. (ND) Not detected. The number above each bar indicates the number of animals used. Error bars indicate the SEM. $(*) P<0.05,(* *) P<0.001$ compared with activin in the hippocampus of ABI mice in the absence of DOX, as determined by one-way ANOVA followed by Fisher's LSD test.

risk-taking behavior test, to examine the anxiety levels of FBItTA and ABItTA mice. In a risk-taking behavior test the amount of time spent in the center of an open field strongly correlates with an animal's level of anxiety (Ageta et al. 2008). The doubletransgenic FBItTA and ABItTA mice showed normal anxiety-like behavior in the light-dark and risk-taking behavior tests (Supplemental Fig. S4A,B), suggesting that these mice show normal responses compared with the mutant mice used in previous work (ACM and FSM, respectively; Ageta et al. 2008). Furthermore, the performance of the double-transgenic mice
(ABItTA and FBItTA) was comparable to single-transgenic mice (ABI and FBI) in sensitivity to electric footshock (Supplemental Fig. S4C). Neurogenesis in the adult hippocampus was reduced in FBItTA mice, but the reduction was less severe than in FSM mice (Supplemental Fig. S5). Therefore, the observed reduction in neurogenesis in FBItTA mice has no influence on the anxiety level. The differences in anxiety phenotype may be, perhaps, due to different follistatin levels in the brain. The FSM mice exhibited a high level of follistatin expression compared with FBItTA mice (Ageta et al. 2008). 

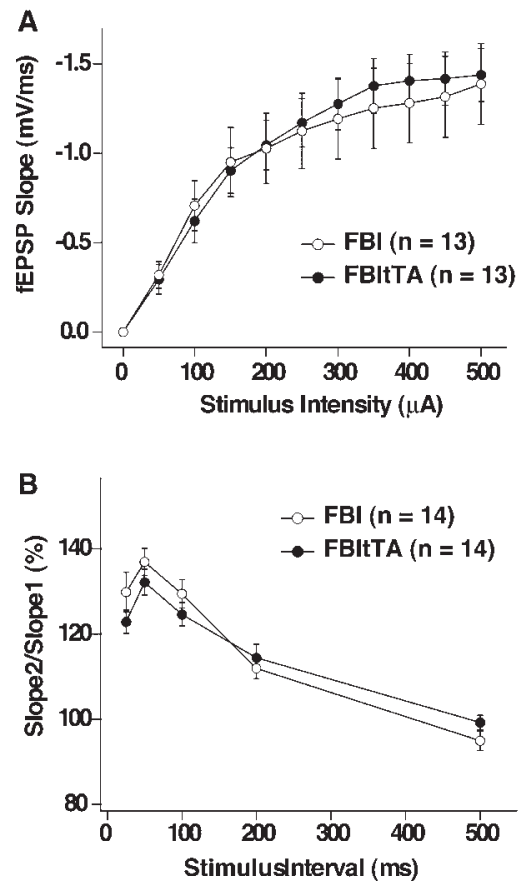

Figure 3. The maintenance of CA1 L-LTP in hippocampal slices from FBItTA mice is reduced as compared with $\mathrm{FBI}$ mice. $(A)$ Input-output curve of fEPSP slope (millivolt [mV]/millisecond [msec]) versus stimulus (microampere $[\mu \mathrm{A}]$ ) at the Schaffer collateral-CA1 pyramidal cell synapse in FBItTA and FBI mice. Data are presented as means \pm SEM. (B) Paired-pulse ratio of fEPSPS in FBItTA and FBI mice. The initial slope of the fEPSP was measured in order to quantify the strength of the synaptic response. The ratio of the second to first response is plotted against the interstimulus interval. Data are presented as means \pm SEM. (C) E-LTP and L-LTP elicited by three $100-\mathrm{Hz}$ trains spaced at 20-msec intervals in FBItTA and FBI mice. The fEPSP slopes elicited by stimulation of the second independent pathway at $0.017 \mathrm{~Hz}$ were stable throughout the experiments. (Insets) Representative fEPSP traces taken at the times indicated on the graphs in $C .\left(^{*}\right) P=0.05$, (NS) not significant.

\section{Once-consolidated fear memory is weakened by follistatin overexpression during the retrieval phase}

We performed contextual fear-conditioning tests on FBItTA and FBI mice in the absence of DOX (Fig. 4, Experiment A). A 1-d retention test showed a significant reduction in the freezing response in FBItTA mice in Test-1 (1 d after conditioning) and Test-2 ( $2 \mathrm{~d}$ after conditioning) compared with FBI mice. There was no significant genotype effect on STM formation (Fig. 4, Experiment B). These results are consistent with the requirement for activin in L-LTP (Figs. 1A, 3C). When transgene expression was turned off by administration of DOX (orange bars, Fig. 4) for 3 consecutive days prior to conditioning, the 1-d memory of FBItTA mice was normal (Fig. 4, Experiment C, Test-1). This result indicates that follistatin expression during development of FBItTA mice did not affect the formation of neuronal circuits that are involved in contextual fear conditioning. Thus, LTM consolidation, but not short-term memory, requires activin activity in the forebrain.

One-week memory tests measured a comparable freezing behavior in FBItTA and FBI mice when DOX was administered for 3 consecutive days before conditioning (Fig. 4, Experiment $\mathrm{D}$, Test-1 [indicated as T1]; Test- 1 was performed $7 \mathrm{~d}$ after conditioning). Thus, the 1-wk memory was normal despite the inhibition of activin signaling during maintenance and retrieval, from day 3 to day 7, when fear conditioning was carried out in the absence of transgene expression. Importantly, when the same animals were retested for freezing behavior $24 \mathrm{~h}$ later, the cin 30 min after the reactivation into wild-type mice, which had been subjected to the same experimental paradigm as in Experiment $\mathrm{E}$, resulted in a reduction in the freezing response in Test $24 \mathrm{~h}$ later (Supplemental Fig. S6). In experiment E, we observed a significant reduction in freezing level in Test-1 (7 d after conditioning) of FBItTA mice compared with FBI mice, strongly suggesting that the reactivation of fear memory in the absence of forebrain activin activity caused the decreased freezing response.

\section{Fear memory is influenced by activin overexpression during the retrieval phase}

A complementary experiment with ABItTA and ABI mice strengthens the idea that forebrain activin is important for proper processing of fear memory following memory reactivation (retrieval) (Fig. 5, Experiment G). In this experiment, we used a relatively weak conditioning protocol to avoid saturation of freezing response. A 3-wk memory test showed a normal freezing response in ABItTA mice compared with ABI mice (Test-1 in Experiment G, $21 \mathrm{~d}$ after conditioning), when the activin level was reduced to the basal level at conditioning by DOX administration. However, when the freezing response of the animals was tested $24 \mathrm{~h}$ later, ABItTA mice showed significantly more freezing than ABI mice (Test-2 in Experiment G, $22 \mathrm{~d}$ after conditioning). Furthermore, we observed a significant increase in freezing level in Test ( $21 \mathrm{~d}$ after conditioning) of ABItTA compared with their 


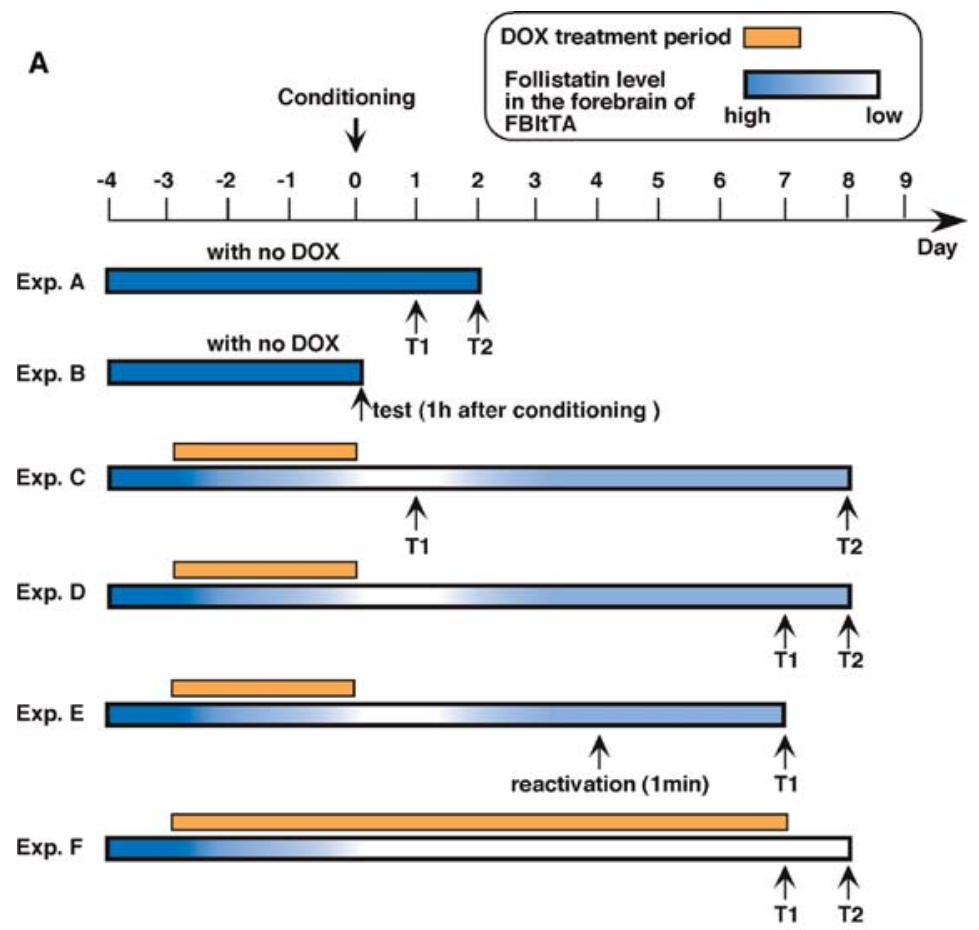

B

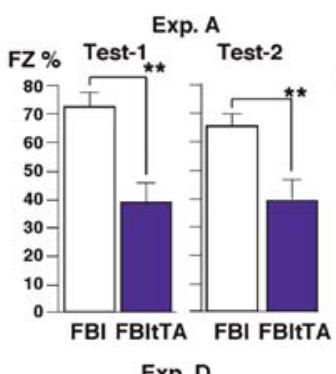

Exp. D

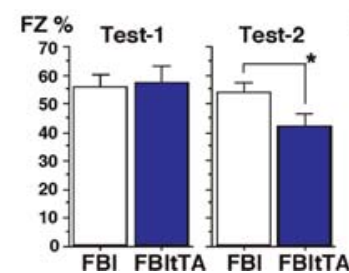

FBI FBItTA FBI FBItTA
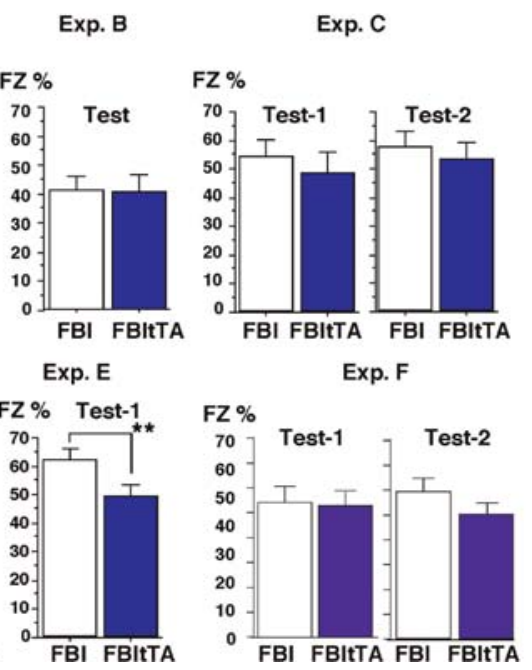

Figure 4. Once-consolidated fear memory is weakened by follistatin overexpression during the retrieval phase. $(A)$ Experimental schedule. The horizontal axis indicates the time line. Mice were fed DOX for 3 consecutive days before conditioning (from noon of day -3 to noon of day 0 ), as indicated (orange bars). The density of blue color indicates the predicted level of follistatin in the forebrain. The numbers of mice used were: Experiment A (FBItTA, $n=8 ; \mathrm{FBI}, n=9$ ); Experiment B (FBItTA, $n=10 ; \mathrm{FBI}, n=10$ ); Experiment C (FBItTA, $n=8 ; \mathrm{FBI}, n=11)$; Experiment D (FBItTA, $n=10 ; \mathrm{FBI}, n=10$ ); Experiment $\mathrm{E}$ (FBItTA, $n=17$; FBI, $n=13$ ); Experiment $\mathrm{F}$ (FBItTA, $n=11 ; \mathrm{FBI}, n=11$ ). In all the experimental paradigms, conditioning was performed in the afternoon of day 0 with the same footshock protocol. (T1) Test-1, (T2) Test-2. (B) Freezing response during the test period. (FZ\%) Average freezing percentage during the 6-min test period. $\left(^{*}\right) P<0.05,\left({ }^{*}\right) P<0.001$, statistically significant differences between FBItTA and FBI mice, as determined by one-way ANOVA followed by Fisher's LSD test. Error bars indicate SEM. Experiment C: Two-way repeated-measures ANOVA, genotype effect, $F_{(1,17)}=0.39$, $P=0.539$; Test effect, $F_{(1,17)}=2.32, P=0.146$; genotype $\times$ Test, $F_{(1,17)}=0.03, P=$ 0.8629. Experiment D: Two-way repeated-measures ANOVA, genotype effect, $F_{(1,17)}=$ $0.71, P=0.4$; Test effect, $F_{(1,17)}=10.16, P=0.0054$; genotype $\times$ Test, $F_{(1,17)}=6.58$, $P=0.02$. Experiment $F$ : Two-way repeated-measures ANOVA, genotype effect, $F_{(1,20)}=$ $0.57, P=0.46$; Test effect, $F_{(1,20)}=0.10, P=0.75$; genotype $\times$ Test, $F_{(1,20)}=2.92, P=$ 0.103 . littermates (ABI and wild-type mice) when conditioned animals were reexposed to the conditioning chamber for $1 \mathrm{~min}$ at $17 \mathrm{~d}$ after conditioning, a time at which forebrain activin was increased in ABItTA (Fig. 5, Experiment H). Taken together, these results indicate that the functional activin level in the forebrain during fear memory retrieval (in this case, Test-1 in Experiment $G$ and reactivation in Experiment $\mathrm{H}$ ) determines the later freezing response (Test-2 in Experiment $G$ and Test in Experiment $\mathrm{H})$.

\section{Discussion}

In this study we showed that activin is indispensable for the late maintenance of hippocampal dentate gyrus L-LTP in vivo and CA1 L-LTP in slice preparation. In the marine snail Aplysia, TGF- $\beta$ induces long-term, but not short-term facilitation at the synapses between the sensory and motor neurons (Zhang et al. 1997). Furthermore, in rat cultured hippocampal neurons, treatment with TGF- $\beta 2$, another isoform of TGF- $\beta$, affected synaptic strength and induced phosphorylation of CREB (Fukushima et al. 2007). Thus, the TGF- $\beta$ family of proteins, namely, activin and TGF- $\beta 1 / 2$, participate not only in development but also in the neuronal plasticity of the mature CNS. In addition, we revealed the existence of prolonged E-LTP in the dentate gyrus, which on the one hand differs from E-LTP in its longer persistence and activin dependency; and on the other differs from L-LTP in its shorter persistence and lack of requirement for protein synthesis. This prolonged E-LTP has been previously described as an intermediate phase LTP (I-LTP) to occur in area CA1 of the hippocampus (Winder et al. 1998). It was found to differ from E-LTP and L-LTP in its molecular mechanisms since it is dependent on protein kinase A, does not require protein synthesis, and is suppressed by calcineurin overexpression. Although it is not clear whether dentate gyrus prolonged E-LTP and CA1 I-LTP share the same molecular mechanisms, it appears that temporally distinct tri-phase LTP is a common characteristic of hippocampal LTPs.

We demonstrated that activin in the brain is required for formation of L-LTP and consolidation of LTM (Figs. 1, 3, and 4). Follistatin failed to suppress L-LTP maintenance when it was administered $3 \mathrm{~h}$ after a strong HFS (Supplemental Fig. S1), and this result is consistent with the behavioral analysis of FBItTA mice. After the acquisition phase, the ectopic expression of follistatin in the maintenance phase did not affect LTM formation (Fig. 4, Experiment D, Test-1), indicating that the presence of follistatin in the maintenance phase has no effect on either L-LTP or LTM. Thus, our results strengthen the correlation between L-LTP and LTM.

There are several mechanisms by which activin may participate in L-LTP and LTM. Activin modulates dendritic spine morphology and increases the number of synaptic contacts (Shoji-Kasai et al. 2007). Activin potentiates NMDA receptormediated signaling cascades for long periods of time (Muller et al. 2006; Kurisaki et al. 2008). In 


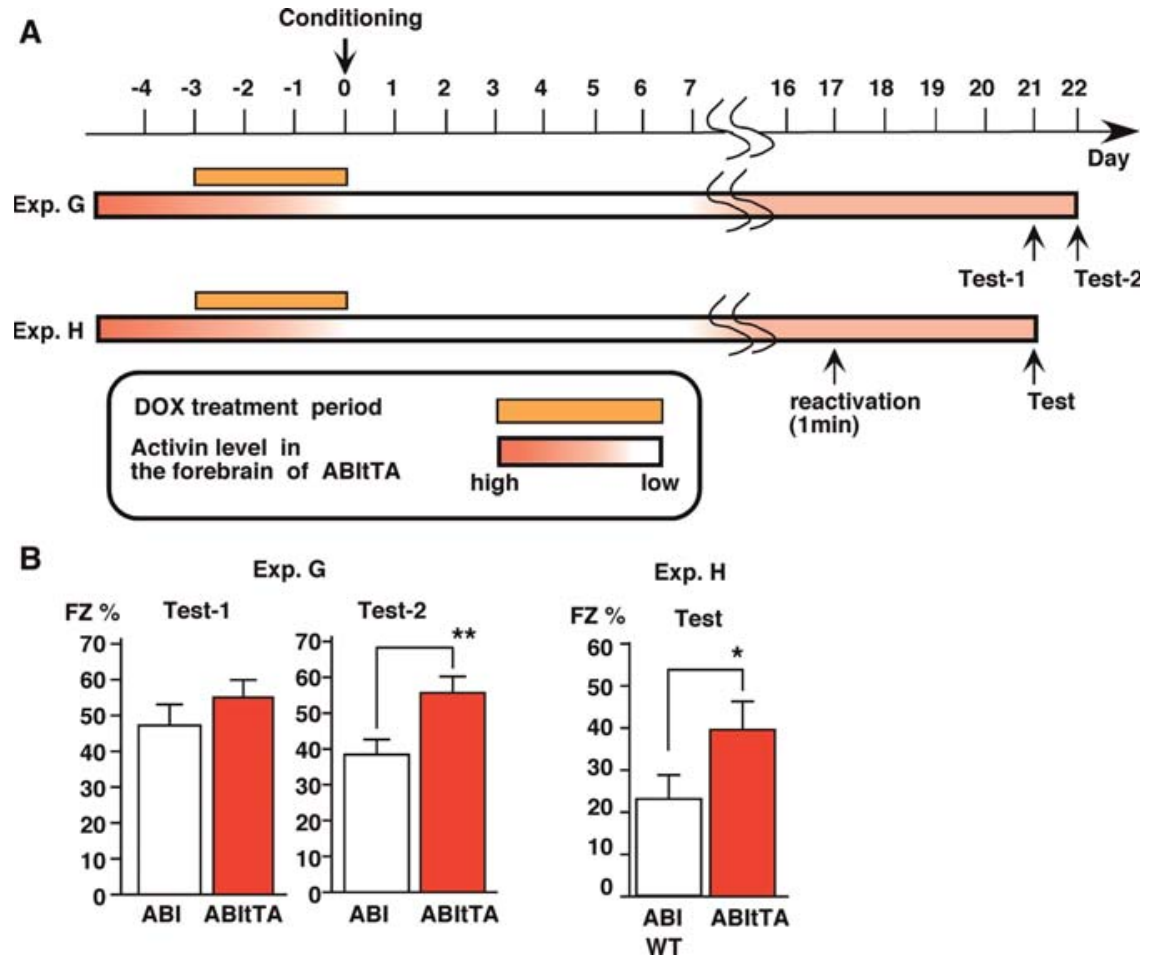

Figure 5. Fear memory is influenced by activin overexpression during the retrieval phase. $(A)$ Experimental schedule. Horizontal axis indicates the time line. Mice were fed DOX for 3 consecutive days before conditioning (from noon of day -3 to noon of day 0 , orange bar). The density of the red color indicates the predicted level of activin in the forebrain. Conditioning was performed in the afternoon of day 0 . (B) Freezing response during test period. (FZ\%) Average freezing percentage during the first $3 \mathrm{~min}$ in the 6 -min test period. The numbers of mice used were: Experiment $\mathrm{G}$ (ABItTA, $n=15 ; \mathrm{ABI}, n=16$ ); Experiment $\mathrm{H}$ (ABItTA, $n=9$; $\mathrm{ABI}, n=5$; wild-type littermates, $n=$ 4). $\left({ }^{*}\right) P=0.05,\left({ }^{*}\right) P=0.001$, statistically significant difference between ABItTA and ABI mice (Experiment $\mathrm{G}$ ) or mixed genotypes $\mathrm{ABI}$ and wild group (Experiment $\mathrm{H}$ ), as determined by one-way ANOVA followed by Fisher's LSD test. Error bars indicate SEM. (WT) Wild-type littermates. Experiment G: Two-way repeated-measures ANOVA, genotype effect, $F_{(1,23)}=4.18, P=0.0526$; Test effect, $F_{(1,23)}=0.70, P=0.410$; genotype $\times$ Test, $F_{(1,23)}=1.63, P=0.214$.
Experiment $\mathrm{G}(P=0.008$, one-way ANOVA with Fisher's test). As the experimental condition used in Experiment $\mathrm{H}$ may trigger extinction by the short-time reactivation, control mice showed a lower level of freezing in Experiment $\mathrm{H}$ when compared with Test-1 in Experiment G. Unfortunately, we could not record the freezing level during the reactivation phase in Experiment $\mathrm{H}$ because of the short period of time (reactivation took a total of $1 \mathrm{~min}$, which included transportation time from the home cage to the test chamber located in a soundproof room [15 sec], exposure time to the chamber [30 sec], and another transportation time from the chamber to the home cage [15 sec]). Taken together, the suppression of freezing observed in Experiments D and E could be caused by inhibition of reconsolidation. On the other hand, the constant level of freezing in ABItTA mice observed in Experiments $\mathrm{G}$ and $\mathrm{H}$ could be attributed to the inhibition of extinction. In any case, the level of activin in the brain during the retrieval phase plays a key role in the maintenance of LTM.

Recent studies show that fear memory can be weakened by inhibiting CREB (Kida et al. 2002), zif268 (Lee et al. 2004), $\mathrm{C} / \mathrm{EBP} \beta$ (Tronel et al. 2005), ERK (Kelly et al. 2003), or PKA (Tronson et al. 2006) during memory retrieval. The present study shows that activin inhibition during memory retrieval suppresses previously consolidated fear memories. Thus, activin signaling could be a promising target for treatment of disorders that are based upon strong traumatic memories, such as post traumatic stress disorder and phobias. addition, activin tunes GABAergic neurotransmission (Zheng et al. 2008), which affects learning and memory (Collinson et al. 2002). All of these activin functions may contribute to the prolonged synaptic plasticity that may underlie LTM formation.

Inhibition of the activin signal during retrieval resulted in a significant suppression of subsequent expression of fear memory (Fig. 4, Experiment D, Test-2). Memory retrieval triggers two opposing processes, reconsolidation or extinction (Tronson and Taylor 2007; Quirk and Mueller 2008). Whether reconsolidation or extinction follows memory retrieval depends on the experimental conditions, such as training and retrieval conditions (Suzuki et al. 2004; Tronson and Taylor 2007). When reconsolidation dominates following memory retrieval, amnesic reagents reduce subsequent memory expression (Nader et al. 2000; Tronson and Taylor 2007). We injected the protein synthesis inhibitor anisomycin $30 \mathrm{~min}$ after reactivation (retrieval) into wild-type mice that had been subjected to the same experimental paradigm as in Experiment $\mathrm{E}$ of Figure 4. We observed a reduction in the fear response in Test (Supplemental Fig. S6). This suggests that the experimental condition used in Experiment E triggers reconsolidation. In addition, we observed that there was no significant extinction effect in control mice in Experiment $\mathrm{D}(P=$ 0.7839 , one-way analysis of variance [ANOVA] with Fisher's test). On the other hand, in Experiment $\mathrm{H}$ in control mice, the freezing level was significantly lower than that of Test- 1 in

\section{Materials and Methods}

\section{Animals}

Male Wistar rats (5-6 mo old) were used for the LTP experiments. All procedures involving the use of animals complied with the National Institutes of Health guidelines for the care and use of laboratory animals and were approved by the Animal Care and Use Committee of the Mitsubishi Kagaku Institute of Life Sciences.

All behavior experiments were conducted in a blind fashion on male mice. Two weeks before behavioral analysis, animals were housed individually in plastic cages and maintained on a 12:12 h light:dark cycle. Food and water were provided ad libitum. The mice were handled daily for $7 \mathrm{~d}$ before behavioral analysis.

\section{Dentate gyrus LTP in vivo}

Dentate gyrus LTP experiments with urethane-anesthetized rats were carried out as described previously (Ikegami et al. 1996; Inokuchi et al. 1996; Ikegami and Inokuchi 2000; Fukazawa et al. 2003) with the following modifications: To avoid subjecting the animals to unnecessary pain, the wound margins were locally infiltrated and anesthetized with $2 \%$ xylocaine. The monopolar recording electrode was then inserted into the hilus of the dentate gyrus $(4.0 \mathrm{~mm}$ posterior, $2.8 \mathrm{~mm}$ lateral, $3.0 \mathrm{~mm}$ ventral to the dura). The bipolar stimulating electrode was positioned ipsilaterally to the medial perforant pathway $(8.0 \mathrm{~mm}$ posterior, $4.0 \mathrm{~mm}$ lateral, $3.0 \mathrm{~mm}$ ventral to the dura). The stimulus intensities 
were set at the current that evoked $50 \%$ of the maximum population spike amplitude and were kept constant throughout the experiment. Test stimuli were delivered at 30-sec intervals to record the fEPSP. After recording a stable basal transmission for $30 \mathrm{~min}$, an HFS was delivered and the fEPSPs were recorded for $24 \mathrm{~h}$. In the follistatin infusion experiments, a strong HFS was used, which consisted of five trains of 400 pulses at $400 \mathrm{~Hz}$ at 2-min intervals. In the activin infusion experiments, we used a weak HFS, which consisted of 50 pulses at $100 \mathrm{~Hz}$. In most experiments, an HFS (100 pulses at $100 \mathrm{~Hz})$ was given after the 24-h recording period and responses were recorded for a further $60 \mathrm{~min}$. The initial EPSP slopes are shown as a percentage of the mean value obtained in the $15 \mathrm{~min}$ immediately prior to delivery of the HFS. To determine whether the magnitude of LTP differed among the groups, responses from the last 15 min block of recording for each $60 \mathrm{~min}$ period were compared statistically. The data are expressed as means \pm standard error of the mean (SEM) and were analyzed by one-way or two-way ANOVA followed by Fisher's least significant difference (LSD) test.

\section{Drug infusions}

Follistatin and activin were prepared from bovine follicular fluid as described previously (Nakamura et al. 1992). Follistatin and activin were dissolved in $50 \mathrm{mM}$ phosphate-buffered saline (PBS, pH 7.4) containing $0.125 \%$ bovine serum albumin (BSA). Anisomycin (Sigma-Aldrich) was dissolved in equimolar $\mathrm{HCl}$, diluted with saline, and adjusted to $\mathrm{pH} 7.4$ with $\mathrm{NaOH}$.

In the experiments shown in Figure 1, activin, follistatin, antiactivin A, or the vehicle solution (PBS containing $0.125 \% \mathrm{BSA}$ ) were infused $45 \mathrm{~min}$ prior to the first HFS delivery. Anisomycin was infused $60 \mathrm{~min}$ prior to the first HFS delivery. The drugs were infused into the left lateral ventricle $(1.0 \mathrm{~mm}$ posterior to the bregma, $1.8 \mathrm{~mm}$ lateral, $3.5 \mathrm{~mm}$ ventral to the dura) ipsilateral to the recording site with a 27-gauge microsyringe. The drug solution (total volume of $2.0 \mu \mathrm{L}$ ) was infused at a rate of $0.5 \mu \mathrm{L} / \mathrm{min}$ and the microsyringe was left in place for $5 \mathrm{~min}$ after the injection.

In the experiments shown in Figure 2, activin, follistatin, or vehicle solution (PBS containing $0.125 \%$ BSA) were injected at 1 or $3 \mathrm{~h}$ after the first HFS delivery using a cannula device (brain infusion kit, Alzet) that had been implanted into the lateral ventricle and connected to a microsyringe. The drug solution (total volume of $2.0 \mu \mathrm{L}$ ) was infused at a rate of $0.5 \mu \mathrm{L} / \mathrm{min}$.

\section{Transgenic mice}

To generate the transgene vectors, we used the pBI-G plasmid (Clontech), which has a multiple cloning site, TRE promoter, a LacZ gene, and $\beta$-globin poly A and SV40 poly A sequences (Fig. 2A). We introduced a XhoI-FseI-PacI-HindIII-AscI site to the NotI site of pBI-G and refer to this plasmid as pBI-G2. Coding sequences for activin and follistatin were isolated by AscI-XhoI digestion from the pCaM-activin-Myc and pCaM-follistatin-Myc plasmids (Ageta et al. 2008), respectively, and inserted into the AscI-XhoI-digested pBI-G2 to generate the pBI-G2-activin-Myc and pBI-G2-follistatin-Myc plasmids. AseI fragments were isolated from pBI-G2-activin-Myc or pBI-G2-follistatin-Myc and microinjected into the pronuclei of one-cell embryos of C57BL/6J mice to produce transgenic mice (Hogan et al. 1994). Microinjected embryos were transferred to the oviducts of pseudopregnant females. We purchased tTA mice (B6; CBA-TgN [CamK2tTA]1Mmay) from the Jackson Laboratory (Maine), and these mice were backcrossed for six generations to the C57BL/6J background mice before crossing with FBI mice. Littermate single transgenic mice, FBI and ABI, were used as controls against FBItTA and ABItTA mice, respectively. Male mice 70-100 d old were used for behavioral analysis. Mice were fed DOX (Sigma, D-9891, $6 \mathrm{mg} / \mathrm{g}$ food) for 3 consecutive days where indicated. The founder mice and offspring were identified by Southern blot analysis using the LacZ gene as a probe and PCR analysis using two independent transgene-specific primer pairs. Forward (f) and reverse (r) PCR primers for genotyping were as follows: tTA, f-5'-TGCCGCCA TTATTACGACAA-3' and r-5'-TCCTCGCCGTCTAAGTGGAG-3',
f-5'-TTGCGTATTGGAAGATCAAG-3' and r-5'-GATGGTAGACCC GTAATTGT-3'; FBI, f-5'-TATTCGCGTAAGGAAATCCA-3' and r-5'-GCCGAGTTTGTCAGAAAGCA-3', f-5'-TCCTTGCTCAGTTCG GTCTT-3' and r-5'-CCCCACTTTGCGTTTCTTCT-3'; ABI, f-5'-TA TTCGCGTAAGGAAATCCA- $3^{\prime}$ and r-5'-GCCGAGTTTGTCAGAA AGCA-3', f-5'-ATCTCCACATACCCGTTCTC-3' and r-5'-CTCCC CACTTTGCGTTTCTT-3'.

\section{X-gal staining}

Animals were sacrificed using an overdose of anesthesia, and the brains were dissected and immediately frozen on dry ice. Cryostat sections $(20-\mu \mathrm{m}$ thick) were cut and mounted onto polylysine-coated glass slides. Sections were air-dried and stored at $80^{\circ} \mathrm{C}$ until use in X-gal staining. X-gal staining was carried out as described (Takeuchi et al. 1995).

\section{CA1 LTP in slice preparation}

Transversely cut hippocampal slices $(300 \mu \mathrm{m})$ were prepared from 6- to 10-wk-old transgenic FBI and FBItTA mice, and were immersed in ice-cold artificial cerebrospinal fluid (ACSF). ACSF was saturated with $95 \% \mathrm{O}_{2} / 5 \% \mathrm{CO}_{2}$, and contained: $124 \mathrm{mM}$ $\mathrm{NaCl}, 3 \mathrm{mM} \mathrm{KCl}, 2.4 \mathrm{mM} \mathrm{CaCl}_{2}, 1.2 \mathrm{mM} \mathrm{MgCl}_{2}, 26 \mathrm{mM}$ $\mathrm{NaHCO}_{3}, 1 \mathrm{mM} \mathrm{NaH} \mathrm{PO}_{4}$, and $10 \mathrm{mM}$ D-glucose. Slices were maintained in ACSF at room temperature for at least $1 \mathrm{~h}$ before recording. They were then transferred to a submersion chamber and perfused continuously $(2 \mathrm{~mL} / \mathrm{min})$ with $\mathrm{ACSF}$ at $30^{\circ} \mathrm{C}$. Schaffer collaterals were stimulated with 0.1 -msec pulses using bipolar tungsten electrodes. fEPSPs were recorded extracellularly in the stratum radiatum of the CA1 region using glass microelectrodes filled with ACSF (tip resistance ca. 3-6 M $\Omega$ ). Stimulus intensities were set to evoke $30 \%-50 \%$ of the maximal fEPSP slope. LTP was induced after recording a stable 15- to 30-min baseline fEPSP. The test pulse frequency was $0.05 \mathrm{~Hz}$. For some of the experiments, two stimulating electrodes were positioned in the stratum radiatum layer to activate two independent sets of Schaffer collaterals. Pathway independence was assessed by applying two pulses with 100-msec interpulse intervals and confirming the absence of PPF between the pathways (collision test). After baseline stimulation the pathway stimulated at $0.05 \mathrm{~Hz}$ received one or three trains of tetanic stimulation at a frequency of $100 \mathrm{~Hz}$ for $1 \mathrm{sec}$ at 20 -sec intervals. The second pathways were stimulated at $0.017 \mathrm{~Hz}$ and served as a control.

Electrophysiological data were collected from two strains of transgenic mice on alternate days using PowerLab (ADInstruments) and three EPC series amplifiers (HEKA Electronik). Data were low-pass filtered $(1 \mathrm{kHz})$ and sampled at $10 \mathrm{kHz}$. As a measure of synaptic strength, the initial slope of the evoked fEPSPs was calculated and expressed as percent change from the baseline mean. Error bars denote SEM values. All data were used for analysis unless the pipette resistance deviated more than 30\% from baseline values or the stimulus artifact, or the shape of fiber volleys changed significantly. To test for group differences between LTP values across conditions, a Student's $t$-test was performed.

\section{Contextual fear conditioning}

After the risk-taking behavior test and light/dark test, we performed the contextual fear conditioning test on each experimental group. For the experiments in Figure 4, 2 min after putting the mice into a chamber, mice received electrical footshocks three times $(0.5 \mathrm{~mA}, 1 \mathrm{sec}$, intershock interval of $1 \mathrm{~min})$. After the shock they remained in the chamber for an additional $2 \mathrm{~min}$. For experiments in Figure 5, 2 min after putting the mice into a chamber, mice received electrical footshocks four times $(0.2 \mathrm{~mA}, 0.5 \mathrm{sec}$, intershock interval of $3 \mathrm{sec}$ ). After the shock they remained in the chamber for an additional $4 \mathrm{~min}$. To monitor the freezing response in the test, mice were again put into the same chamber for $6 \mathrm{~min}$, except for Test- 1 of experiment A (duration, $1 \mathrm{~min}$ ) in Figure 4. Freezing behavior, which is defined as no movement during consecutive 2-sec intervals, was analyzed by an automated imaging system (Muromachi Kagaku). In Experiments $\mathrm{E}$ and $\mathrm{H}$, reactivation took a total of $1 \mathrm{~min}$, which included transportation 
time from the home cage to the test chamber located in a soundproof room $(15 \mathrm{sec})$, exposure time to the chamber $(30 \mathrm{sec})$, and another transportation time from the chamber to the home cage (15 sec).

\section{Sensitivity to electrical stimulation}

After the contextual fear-conditioning test, we measured the sensitivity of mice to footshock (Supplemental Fig. S4C). In this test, each mouse is placed in a conditioning chamber and receives 1-sec shocks of increasing intensity (Inoue et al. 2009). The interval between shocks is $10 \mathrm{sec}$. The sequence of the current used was as follows: $0.05 \mathrm{~mA}, 0.08 \mathrm{~mA}, 0.1 \mathrm{~mA}, 0.2 \mathrm{~mA}, 0.3 \mathrm{~mA}, 0.4 \mathrm{~mA}$, $0.5 \mathrm{~mA}, 0.6 \mathrm{~mA}$, and $0.8 \mathrm{~mA}$. The minimal level of current required to elicit the stereotypical responses of running, vocalization, and jumping was determined.

\section{Miscellaneous methods}

ELISA and analysis of neurogenesis were carried out essentially as described previously (Ageta et al. 2008). Behavioral analyses, including the risk-taking behavior and light/dark tests, were carried out as described (Ageta et al. 2008).

\section{Acknowledgments}

We thank Y. Saitoh for valuable suggestions for the behavior tests; E. Tokunaga for genotyping the transgenic mice; T. Takeuchi for advice on X-gal staining; S. Kamijo, M. Matsuo, K. Kawaguchi, and M. Yamashita for maintenance of the transgenic mice; H. Fukushima for advice on the behavior test; and members of the Inokuchi laboratory for helpful discussions. This work was supported by Special Coordinate Funds for Promoting Science and Technology, and in part by a Grant-inAid for Scientific Research on the Priority Area "Molecular Brain Science" from the Ministry of Education, Culture, Sports, Science, and Technology of Japan to K.I.

\section{References}

Abdipranoto-Cowley A, Park JS, Croucher D, Daniel J, Henshall S, Galbraith S, Mervin K, Vissel B. 2009. Activin A is essential for neurogenesis following neurodegeneration. Stem Cells 27: $1330-1346$.

Abraham WC, Mason SE, Demmer J, Williams JM, Richardson CL, Tate WP, Lawlor PA, Dragunow M. 1993. Correlations between immediate early gene induction and the persistence of long-term potentiation. Neuroscience 56: 717-727.

Ageta H, Murayama A, Migishima R, Kida S, Tsuchida K, Yokoyama M, Inokuchi K. 2008. Activin in the brain modulates anxiety-related behavior and adult neurogenesis. PLOS ONE 3: e1869. doi: 10.1371/ journal.pone.0001869.

Andreasson K, Worley PF. 1995. Induction of $\beta$-A activin expression by synaptic activity and during neocortical development. Neuroscience 69: $781-796$.

Bourtchuladze R, Frenguelli B, Blendy J, Cioffi D, Schutz G, Silva AJ. 1994. Deficient long-term memory in mice with a targeted mutation of the cAMP-responsive element-binding protein. Cell 79: 59-68.

Cameron VA, Nishimura E, Mathews LS, Lewis KA, Sawchenko PE, Vale WW. 1994. Hybridization histochemical localization of activin receptor subtypes in rat brain, pituitary, ovary, and testis. Endocrinology 134: $799-808$.

Collinson N, Kuenzi FM, Jarolimek W, Maubach KA, Cothliff R, Sur C, Smith A, Otu FM, Howell O, Atack JR, et al. 2002. Enhanced learning and memory and altered GABAergic synaptic transmission in mice lacking the $\alpha 5$ subunit of the GABAA receptor. J Neurosci 22: $5572-5580$.

Dow AL, Russell DS, Duman RS. 2005. Regulation of activin mRNA and Smad2 phosphorylation by antidepressant treatment in the rat brain: Effects in behavioral models. J Neurosci 25: 4908-4916.

Frey U, Krug M, Reymann KG, Matthies H. 1988. Anisomycin, an inhibitor of protein synthesis, blocks late phases of LTP phenomena in the hippocampal CA1 region in vitro. Brain Res 452: 57-65.

Fukazawa Y, Saitoh Y, Ozawa F, Ohta Y, Mizuno K, Inokuchi K. 2003. Hippocampal LTP is accompanied by enhanced F-actin content within the dendritic spine that is essential for late LTP maintenance in vivo. Neuron 38: 447-460.
Fukushima T, Liu RY, Byrne JH. 2007. Transforming growth factor- $\beta 2$ modulates synaptic efficacy and plasticity and induces phosphorylation of CREB in hippocampal neurons. Hippocampus 17: $5-9$.

Funaba M, Murata T, Fujimura H, Murata E, Abe M, Torii K. 1997. Immunolocalization of type I or type II activin receptors in the rat brain. J Neuroendocrinol 9: 105-111.

Hegde AN, Inokuchi K, Pei W, Casadio A, Ghirardi M, Chain DG, Martin KC, Kandel ER, Schwartz JH. 1997. Ubiquitin C-terminal hydrolase is an immediate-early gene essential for long-term facilitation in Aplysia. Cell 89: 115-126.

Hirao K, Hata Y, Ide N, Takeuchi M, Irie M, Yao I, Deguchi M, Toyoda A, Sudhof TC, Takai Y. 1998. A novel multiple PDZ domaincontaining molecule interacting with $\mathrm{N}$-methyl-D-aspartate receptors and neuronal cell adhesion proteins. J Biol Chem 273: 21105-21110.

Hogan B, Beddington R, Constantini F, Lacy E. 1994. Manipulating the mouse embryo: A laboratory manual. Cold Spring Harbor Laboratory Press, Cold Spring Harbor, New York.

Ikegami S, Inokuchi K. 2000. Antisense DNA against calcineurin facilitates memory in contextual fear conditioning by lowering the threshold for hippocampal long-term potentiation induction. Neuroscience $\mathbf{9 8 :}$ $637-646$.

Ikegami S, Kato A, Kudo Y, Kuno T, Ozawa F, Inokuchi K. 1996. A facilitatory effect on the induction of long-term potentiation in vivo by chronic administration of antisense oligodeoxynucleotides against catalytic subunits of calcineurin. Brain Res Mol Brain Res 41: 183-191.

Inokuchi K, Kato A, Hiraia K, Hishinuma F, Inoue M, Ozawa F. 1996. Increase in activin $\beta A$ mRNA in rat hippocampus during long-term potentiation. FEBS Lett 382: 48-52.

Inoue N, Nakao H, Migishima R, Hino T, Matsui M, Hayashi F, Nakao K, Manabe T, Aiba A, Inokuchi K. 2009. Requirement of the immediate early gene vesl-1S/homer-1a for fear memory formation. Mol Brain 2: 7 . doi: 10.1186/1756-6606-2-7.

Kato A, Ozawa F, Saitoh Y, Hirai K, Inokuchi K. 1997. vesl, a gene encoding VASP/Ena family related protein, is upregulated during seizure, long-term potentiation and synaptogenesis. FEBS Lett 412: $183-189$.

Kelly A, Laroche S, Davis S. 2003. Activation of mitogen-activated protein kinase/extracellular signal-regulated kinase in hippocampal circuitry is required for consolidation and reconsolidation of recognition memory. J Neurosci 23: 5354-5360.

Kida S, Josselyn SA, de Ortiz SP, Kogan JH, Chevere I, Masushige S, Silva AJ. 2002. CREB required for the stability of new and reactivated fear memories. Nat Neurosci 5: 348-355.

Kitamura T, Saitoh Y, Takashima N, Murayama A, Niibori Y, Ageta H, Sekiguchi M, Sugiyama H, Inokuchi K. 2009. Adult neurogenesis modulates the hippocampus-dependent period of associative fear memory. Cell 139: 814-827.

Kurisaki A, Inoue I, Kurisaki K, Yamakawa N, Tsuchida K, Sugino H. 2008. Activin induces long-lasting $N$-methyl-D-aspartate receptor activation via scaffolding PDZ protein activin receptor interacting protein 1. Neuroscience 151: 1225-1235.

Lee JL, Everitt BJ, Thomas KL. 2004. Independent cellular processes for hippocampal memory consolidation and reconsolidation. Science 304: $839-843$.

Lee SH, Choi JH, Lee N, Lee HR, Kim JI, Yu NK, Choi SL, Kim H, Kaang BK. 2008. Synaptic protein degradation underlies destabilization of retrieved fear memory. Science 319: 1253-1256.

Massague J. 1998. TGF- $\beta$ signal transduction. Annu Rev Biochem 67: $753-791$.

Mather JP, Moore A, Li RH. 1997. Activins, inhibins, and follistatins: Further thoughts on a growing family of regulators. Proc Soc Exp Biol Med 215: 209-222.

Mayford M, Bach ME, Huang YY, Wang L, Hawkins RD, Kandel ER. 1996. Control of memory formation through regulated expression of a CaMKII transgene. Science 274: 1678-1683.

Muller MR, Zheng F, Werner S, Alzheimer C. 2006. Transgenic mice expressing dominant-negative activin receptor IB in forebrain neurons reveal novel functions of activin at glutamatergic synapses. J Biol Chem 281: 29076-29084.

Nader K. 2003. Memory traces unbound. Trends Neurosci 26: 65-72.

Nader K, Schafe GE, Le Doux JE. 2000. Fear memories require protein synthesis in the amygdala for reconsolidation after retrieval. Nature 406: $722-726$.

Nakamura T, Takio K, Eto Y, Shibai H, Titani K, Sugino H. 1990. Activin-binding protein from rat ovary is follistatin. Science 247: 836-838.

Nakamura T, Asashima M, Eto Y, Takio K, Uchiyama H, Moriya N, Ariizumi T, Yashiro T, Sugino K, Titani K. 1992. Isolation and characterization of native activin B. J Biol Chem 267: $16385-16389$. 
Nguyen PV, Abel T, Kandel ER. 1994. Requirement of a critical period of transcription for induction of a late phase of LTP. Science 265: 1104-1107.

Nicoll RA, Malenka RC. 1999. Expression mechanisms underlying NMDA receptor-dependent long-term potentiation. Ann N Y Acad Sci 868: $515-525$.

Okada D, Ozawa F, Inokuchi K. 2009. Input-specific spine entry of soma-derived Vesl-1S protein conforms to synaptic tagging. Science 324: 904-909.

Pangas SA, Woodruff TK. 2000. Activin signal transduction pathways. Trends Endocrinol Metab 11: 309-314.

Quirk GJ, Mueller D. 2008. Neural mechanisms of extinction learning and retrieval. Neuropsychopharmacology 33: 56-72.

Rioult-Pedotti MS, Friedman D, Donoghue JP. 2000. Learning-induced LTP in neocortex. Science 290: 533-536.

Rodrigues SM, Schafe GE, LeDoux JE. 2004. Molecular mechanisms underlying emotional learning and memory in the lateral amygdala. Neuron 44: 75-91.

Rogan MT, Staubli UV, LeDoux JE. 1997. Fear conditioning induces associative long-term potentiation in the amygdala. Nature 390: 604-607.

Sekiguchi M, Hayashi F, Tsuchida K, Inokuchi K. 2009. Neuron type-selective effects of activin on development of the hippocampus. Neurosci Lett 452: 232-237.

Shoji H, Tsuchida K, Kishi H, Yamakawa N, Matsuzaki T, Liu Z, Nakamura T, Sugino H. 2000. Identification and characterization of a PDZ protein that interacts with activin type II receptors. J Biol Chem 275: $5485-5492$.

Shoji-Kasai Y, Ageta H, Hasegawa Y, Tsuchida K, Sugino H, Inokuchi K. 2007. Activin increases the number of synaptic contacts and the length of dendritic spine necks by modulating spinal actin dynamics. J Cell Sci 120: $3830-3837$.

Silva AJ, Kogan JH, Frankland PW, Kida S. 1998. CREB and memory. Annu Rev Neurosci 21: $127-148$.

Squire LR, Barondes SH. 1973. Memory impairment during prolonged training in mice given inhibitors of cerebral protein synthesis. Brain Res 56: $215-225$

Sugino H, Sugino K, Hashimoto O, Shoji H, Nakamura T. 1997. Follistatin and its role as an activin-binding protein. J Med Invest 44: 1-14.
Suzuki A, Josselyn SA, Frankland PW, Masushige S, Silva AJ, Kida S. 2004 Memory reconsolidation and extinction have distinct temporal and biochemical signatures. J Neurosci 24: 4787-4795.

Takeuchi T, Yamazaki Y, Katoh-Fukui Y, Tsuchiya R, Kondo S, Motoyama J, Higashinakagawa T. 1995. Gene trap capture of a novel mouse gene, jumonji, required for neural tube formation. Genes \& Dev 9 : 1211-1222.

Tretter YP, Hertel M, Munz B, ten Bruggencate G, Werner S, Alzheimer C. 2000. Induction of activin A is essential for the neuroprotective action of basic fibroblast growth factor in vivo. Nat Med 6: 812-815.

Tronel S, Milekic MH, Alberini CM. 2005. Linking new information to a reactivated memory requires consolidation and not reconsolidation mechanisms. PLoS Biol 3: e293. doi: 10.1371/ journal.pbio.0030293.

Tronson NC, Taylor JR. 2007. Molecular mechanisms of memory reconsolidation. Nat Rev Neurosci 8: 262-275.

Tronson NC, Wiseman SL, Olausson P, Taylor JR. 2006. Bidirectional behavioral plasticity of memory reconsolidation depends on amygdalar protein kinase A. Nat Neurosci 9: 167-169.

Winder DG, Mansuy IM, Osman M, Moallem TM, Kandel ER. 1998. Genetic and pharmacological evidence for a novel, intermediate phase of long-term potentiation suppressed by calcineurin. Cell 92: $25-37$.

Yao I, Takagi H, Ageta H, Kahyo T, Sato S, Hatanaka K, Fukuda Y, Chiba T, Morone N, Yuasa S, et al. 2007. SCRAPPER-dependent ubiquitination of active zone protein RIM1 regulates synaptic vesicle release. Cell 130: 943-957.

Ying SY, Zhang Z, Furst B, Batres Y, Huang G, Li G. 1997. Activins and activin receptors in cell growth. Proc Soc Exp Biol Med 214: $114-122$.

Zhang F, Endo S, Cleary LJ, Eskin A, Byrne JH. 1997. Role of transforming growth factor- $\beta$ in long-term synaptic facilitation in Aplysia. Science 275: $1318-1320$

Zheng F, Adelsberger H, Muller MR, Fritschy JM, Werner S, Alzheimer C. 2008. Activin tunes GABAergic neurotransmission and modulates anxiety-like behavior. Mol Psychiatry 14: 332-346.

Received October 11, 2009; accepted in revised form February 5, 2010. 


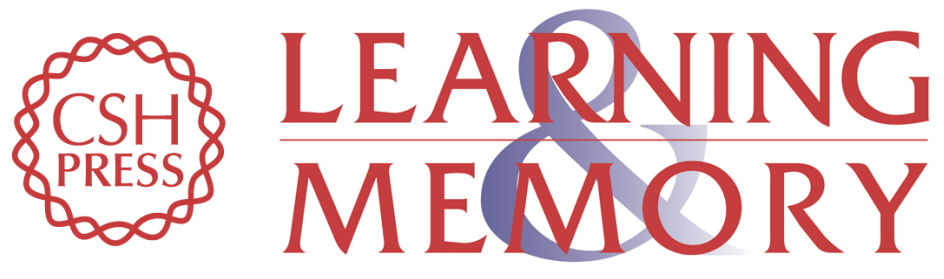

\section{Activin plays a key role in the maintenance of long-term memory and late-LTP}

Hiroshi Ageta, Shiro Ikegami, Masami Miura, et al.

Learn. Mem. 2010, 17:

Access the most recent version at doi:10.1101/lm.16659010

Supplemental
Material http://learnmem.cshlp.org/content/suppl/2010/03/29/17.4.176.DC1

References This article cites 54 articles, 18 of which can be accessed free at: http://learnmem.cshlp.org/content/17/4/176.full.html\#ref-list-1

License

Email Alerting Receive free email alerts when new articles cite this article - sign up in the box at the Service top right corner of the article or click here. 